Ye.V. Kylnytska, Cand. Sc. (Econ.), Assoc. Prof., orcid.org/0000-0002-0586-820X
Kharkiv National University of Civil Engineering And Architecture, Kharkiv, Ukraine, e-mail: dubrochka@ukr.net

\title{
IMPLEMENTATION OF DIFFERENTIATED CREDIT POLICY AT MINING ENTERPRISES
}

Purpose. An experimental introduction of the mechanism of formation of differentiated credit policy at a mining enterprise on the basis of controllability receivables developed by the author.

Methodology. Attainment of the objectives of the article are implemented using modern general and special methods: mathematical modeling - to model the effects of credit policy; abstract logical method - to make theoretical generalizations, formulated conclusions and recommendations. In addition, results of previous studies on the problems of management of accounts receivable are used.

Findings. The mechanism of formation of differentiated credit policy on the basis of controllability receivables represents structured parameters: 1) setting the amount of the working capital invested in receivables and calculating the amount of products on deferred payment terms; 2) developing the system terms of deferred payment (the maximum possible period of deferred payment, the maximum possible amount of deferred payment, discounts for prepayment of receivables); 3) terms differentiation of deferred payment depending on the class of the creditworthiness of customers; 4) appropriateness evaluation of the credit policy by modeling its effects on the formation of profits of the enterprise. As a result of the implementation mechanism of formation of differentiated credit policy to PJSC "Kharkiv Quarry Management" (based on the following data: increase in the value of receivables at the moderate type of credit policy is the negative value -824.196 UAH, confirming its contraction and release of working capital; profit growth on change in the credit policy to moderate type is $193.200 \mathrm{UAH}$ ), it can be said that the moderate type is optimal credit policy that meets the financial and marketing strategies of the enterprise.

Originality. The mechanism of formation of the differentiated credit policy, which, unlike the existing ones, is the synthesis of structured parameters of effective planning, regulation, monitoring, and rational organization of relationships with customers on the reverse movement of cash and appropriate methodological tools that differentiated according to the typology the credit policy (conservative, moderate, aggressive) based on controllability receivables is developed and implemented.

Practical value. The ability to use the developed mechanism of formation of differentiated credit policy to facilitate the effective planning, regulation, monitoring, and rational organization of relationships with customers on the reverse movement of funds to mining enterprise is shown. The experimental introduction of copyright mechanism of formation of the differentiated credit policy on the basis of controllability accounts receivable in marketing and financial activities at the mining enterprise has confirmed its validity and practical significance.

Keywords: credit policy, accounts receivable, controllability, enterprise of mining industries, differentiation

Introduction. Under the influence of an unstable situation in Ukraine, Ukrainian enterprises are not able to manage receivables; the vast majority of domestic enterprises is already on the verge of bankruptcy or is exposed to crisis phenomena, which leads to instability of market relations between economic entities, deterioration of their financial situation and payment discipline. Ineffective and untimely management of accounts receivable leads to the shortage of funds and, as a result, the delay in payables, shortage of inventories, an increase in the need for loan capital, in connection with the immobilization of working capital in accounts receivable, a decrease in the real amount of receivables due to cost escalation processes.

Specific features of the formation of accounts receivable at mining enterprises emphasize the urgency of solving the problem of overcoming the crisis of nonpayment by building a mechanism for the formation of credit policy as the main marketing and financial structural component of the system of accounts receivable planning.

(C) Kylnytska Ye.V., 2018
Analysis of the recent research. In the scientific literature there is presented a wide range of approaches to the formation of the credit policy of enterprises, developed by Ukrainian and foreign scientists: Yu. M.Atamanchuk [1], S.I. Kaminskyi [2], O. V. Klymenko [3], I. Yu. Nosenko [4], V.V. Masalitina [5], L.V.Chupryn, M.A.Sheiter [6], R.Anderson [7], K.Gordon Mills, B. McCarthy [8].

Despite a large range of methodological approaches to the development of credit policy of the enterprise, debating points are still present:

1) the lack of methodical tools for calculating the structural elements of credit policy is inherent in scientific works $[1-3,5]$. Scientists overlook such structural parameters of credit policy as: the term of the delay, the amount of deferral of payment, the value of the deferred payment and the system of penalties;

2) the identity of the methodical foundations for the development of the credit policy of enterprises and the credit policy of financial and credit institutions, which are reflected in the scientific articles [1,2]. Since the methodical toolkit for the formation of credit policy in financial and credit institutions involves the use of a suf- 
ficiently labor-intensive mathematical and statistical base, their application is complicated, and in some cases, it appears impossible for mining enterprises;

3 ) the focus on the development of credit policy, without taking into account its typology, is common for scientific works $[2,4,6]$, which, in our view, makes this approach unacceptable in a changing market environment;

4) inadaptability to foreign methods, set forth in scientific works [7, 8], concerning the formation of credit policy for the opportunities of Ukrainian mining enterprises in both legislative and financial-managerial aspects.

The analysis of published works and the practice of economic activity of enterprises in the mining industry testify the lack of elaboration of fundamentally important issues regarding the mechanism of credit policy formation, adequate to their sector specifics. The lack of structuring of the parameters of the credit policy and the corresponding methodical tools, which is differentiated depending on the typology of credit policy, necessitated the development of a comprehensive mechanism for the formation of differentiated credit policy at mining enterprises, based on the principles of controllability of accounts receivable.

The objective of the article is the application and experimental introduction of the mechanism developed by the author for the formation of a differentiated credit policy at mining enterprises on the issues of controllability of accounts receivable. The following tasks were set and solved for its implementation: the most optimal indicator of the efficiency of management of accounts receivable is determined by the enterprise in the mining industry from the sampled population, the mechanism of formation of differentiated credit policy on the basis of controllability of accounts receivable is determined by calculation of structural elements of the credit policy differentiated according to its typology and the effectiveness of the credit policy is determined.

Presentation of the main research. Since the main objective of the management of accounts receivable combines two diametrically opposite, but interrelated systems of tasks - marketing and financial management, the system of management of accounts receivable in the economy is divided into two major blocks: the credit policy, which allows the most efficient use of accounts receivable as a marketing tool for increasing the volume of services, and a set of measures aimed at reducing the risk of overdue debts. The credit policy is closely linked to the marketing policy of the company, whose purpose is to increase the scope of services provision, and then depending on the level of profitability and risk, different types of the credit policy can be applied. In the scientific literature on economy, scientists [1-4] unanimously distinguish three types of credit policy: conservative, moderate, and aggressive ones.

Adhering to the objective of the article, the structuring of the process of forming a credit policy allowed developing the mechanism for the formation of the differentiated credit policy, which represents structured parameters and appropriate methodical tools, differentiated by types of the credit policy on the basis of controllability of accounts receivable, and allows planning effectively, regulating, controlling, organizing the relationship with customers of mining products in relation to the reverse flow of cash rationally, as well as contributes to the most rational and full capacity utilization at mining enterprises.

Based on the above, the differentiated credit policy for mining enterprises and a cross-cutting example of its implementation are presented in Table.

To select the object of experimental introduction of the mechanism for the formation of the differentiated credit policy based on the principles of controllability of receivables, a number of mining enterprises were investigated according to the criterion of correlation of receivables and receipts and the PJSC "Kharkiv Quarry Management" was selected, reflecting the averaged data in the industry. Based on the results of the statistical analysis of the efficiency of the actual level of management of accounts receivable at PJSC "Kharkiv Quarry Management", the following is established: the absence of the system for assessing the customer's creditworthiness on terms of postponement of payment; in contracts on the supply of products on terms of postponement of payment, there are no penalties for late payment of arrears; a system of discounts for early repayment of debts for products that were shipped on terms of deferral of payment is not provided; planning of relationships with customers of products is carried out without taking into account the differentiation of credit conditions, depending on their class of credit, the credit policy lacks the system of differentiation of terms of deferral of payment, the clear system of penalties, the system of discounts for early payment of services; collection of debts is nonsystematic in nature, which provides only legal methods of influence by collecting debt in court.

The above lead to the conclusion that the system of managing accounts receivable is not comprehensive; it is not adapted to the market conditions of functioning mining enterprises and requires the profound change. Proceeding from the foregoing, the issue of overcoming payment crisis is becoming a matter of urgency by introducing the integrated mechanism for the formation of the credit policy in the marketing and financial activities of PJSC "Kharkiv Quarry Management". The information base for the implementation of the credit policy at PJSC "Kharkiv Quarry Management" is served as financial statements and its notes, on the basis of which it was established that the specific weight of accounts receivable: with a high level of controllability was $27.5 \%$; with an average level of manageability made $51.61 \%$; with a low level of handling was $17.59 \%$. The share of uncontrolled receivables amounted to $3.3 \%$. Retrospective analysis allowed establishing that 997 contracts were concluded on terms of postponement of payment for a period of 30 days, whose weighted average period of delay was 22 days, the minimum and maximum amount of deferral of payment amounted to 17.500 and 1.500 UAH, accordingly. To calculate the value of the deferred payment, the interest rate to cover the working capital deficit is taken at the level of $29 \%$ per annum in the national currency. In order to calculate the amount of delays in payment in value terms, the index of industrial producer prices (extractive industry and quarry development) at the level of $109.1 \%$ was adopted [9]. 


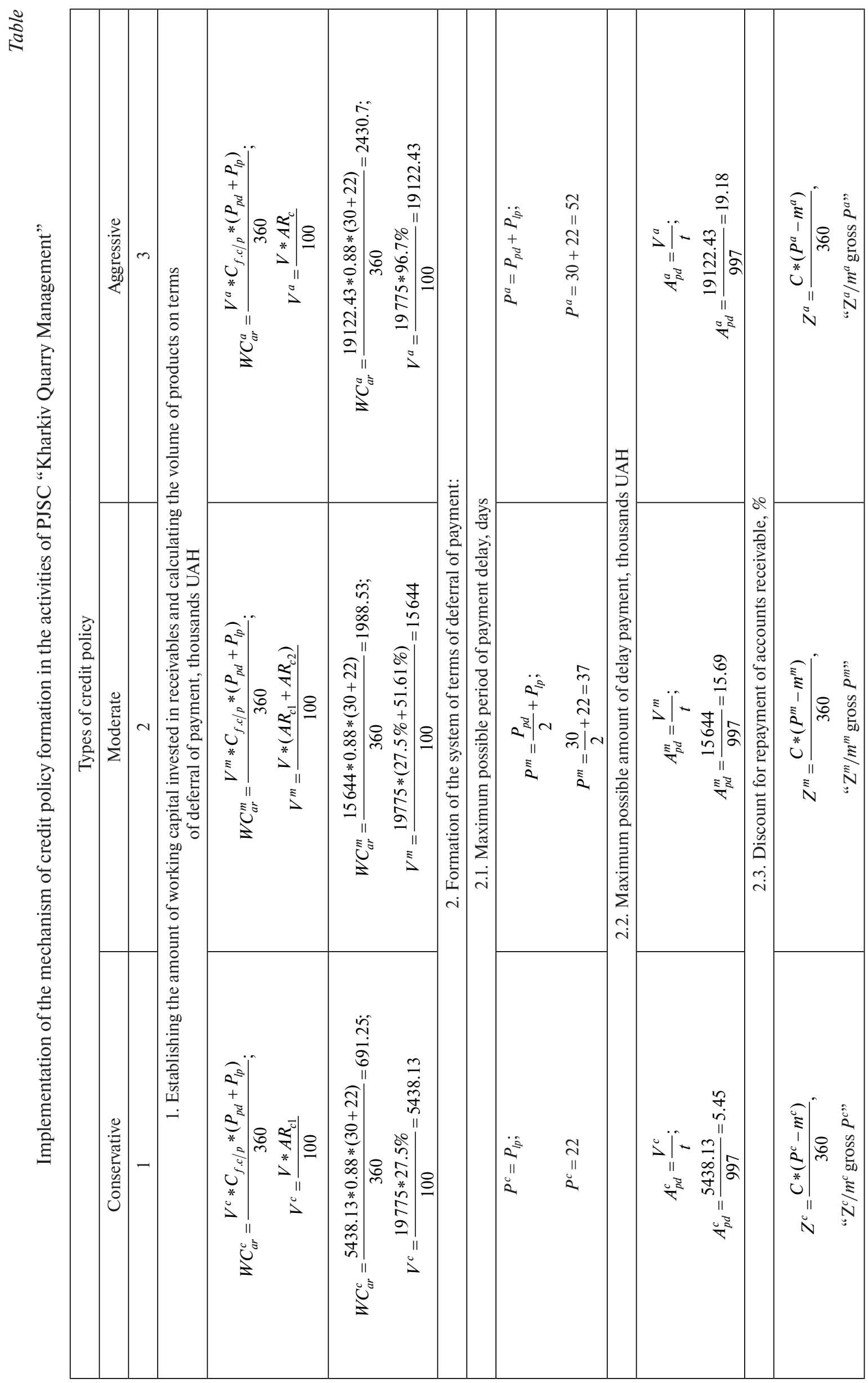




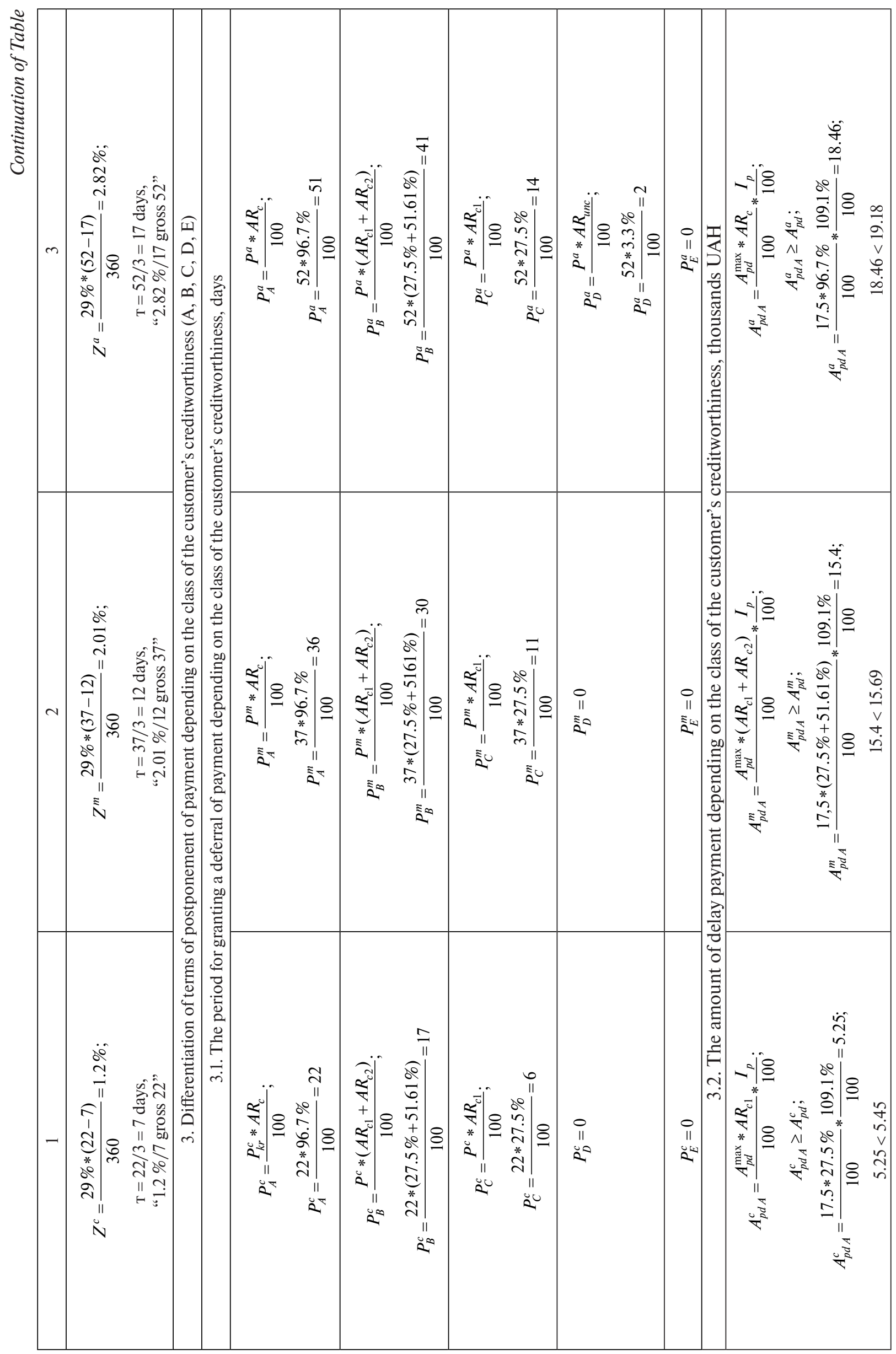




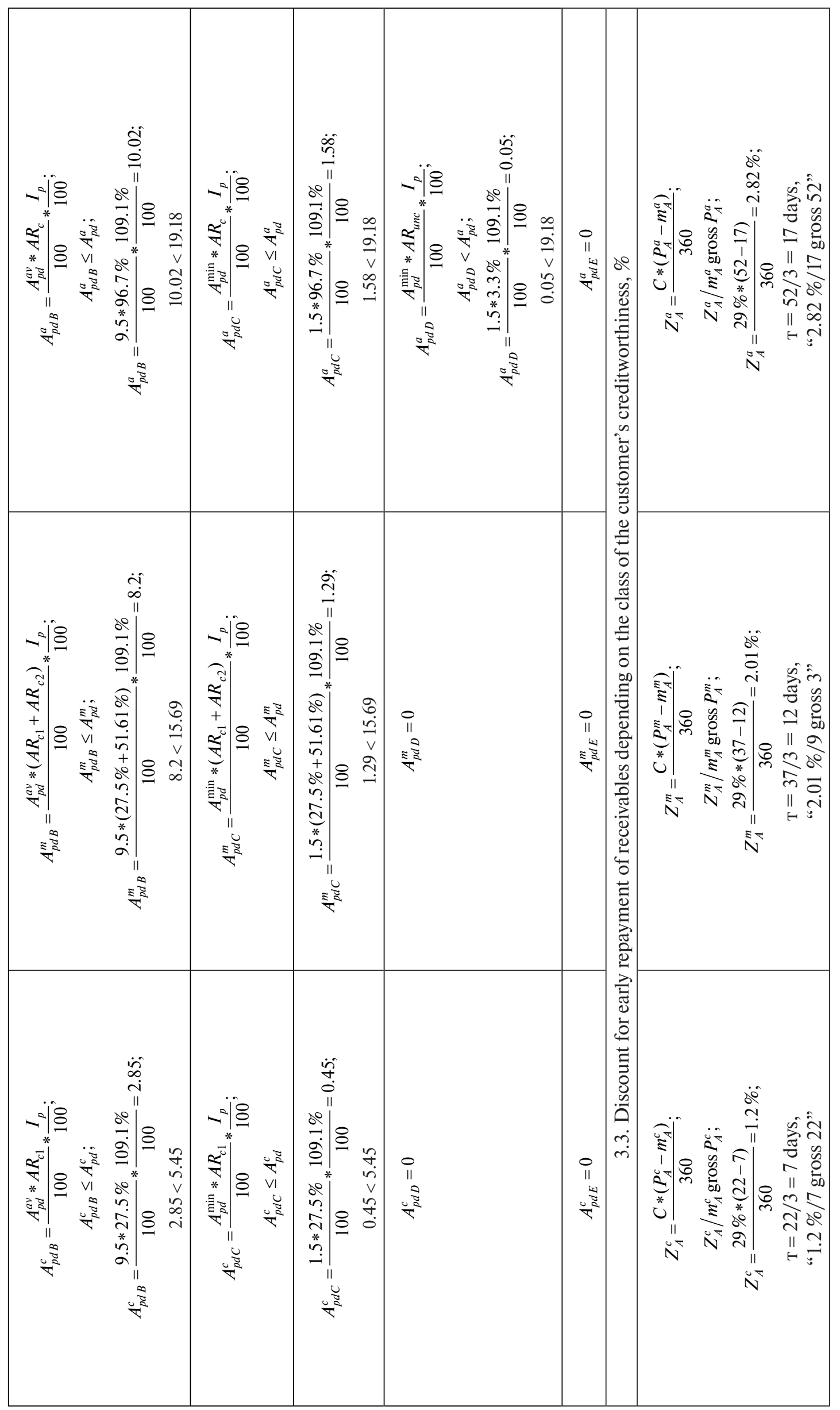




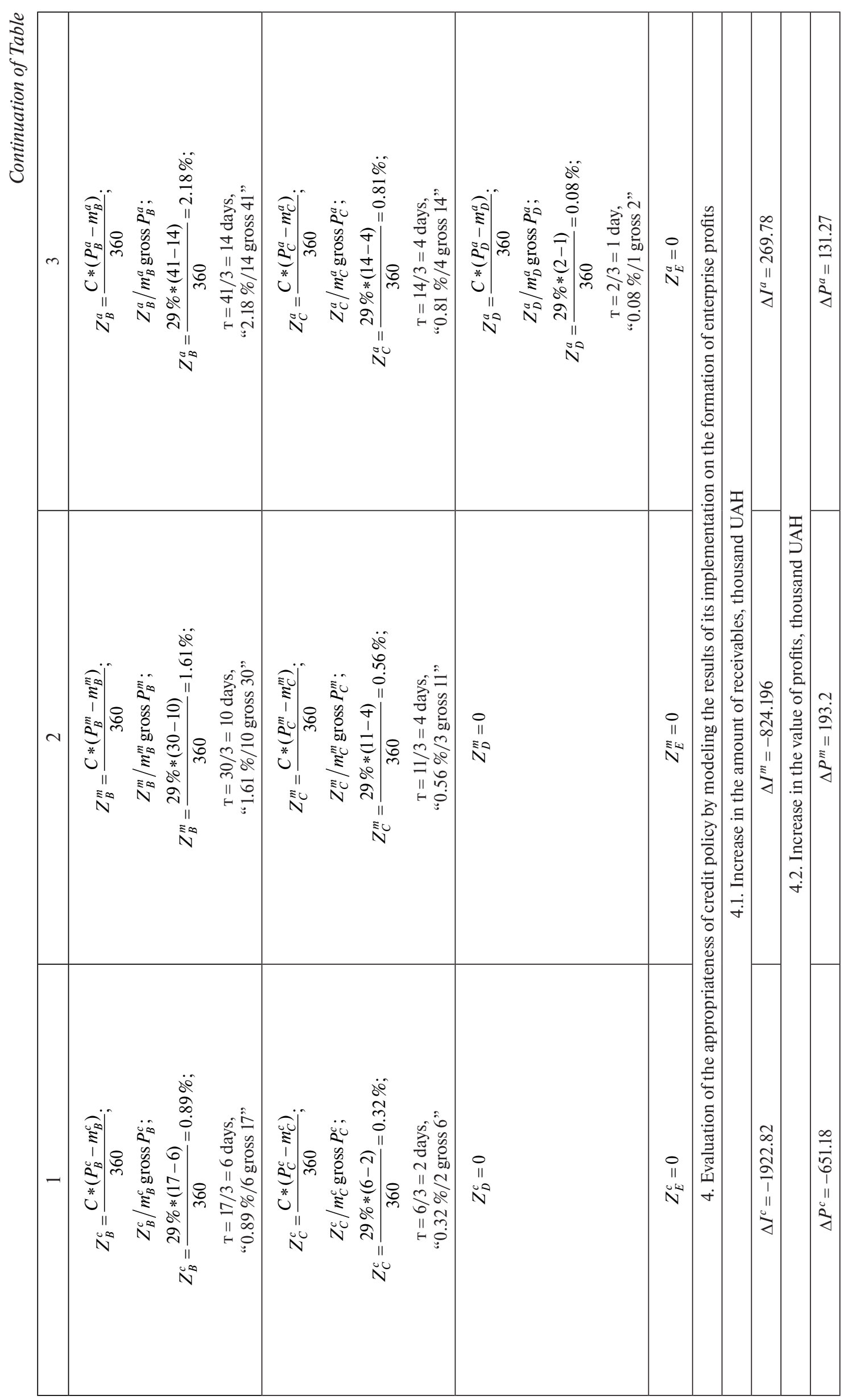


Explanation of symbols: $V$ - the planned volume of products on terms of deferral of payment, thousand $\mathrm{UAH} ; C_{f . c / p}-$ coefficient of the ratio of full cost and price, in the form of a decimal fraction; $P_{p d}$ - average period of payment delay, days; $P_{l p}-$ average period of late payment, days; $A R_{c}$ - share of controllability account receivables in the general structure, $\% ; A R_{c l}$, $A R_{c 2}$ - share of receivables with high and average levels of controllability, \%; $A R_{\text {unc. }}$ - share of uncontrollable receivables, $\%$; $t$ - the average number of transactions for the sale of products on terms of postponement of payment, unit; $A_{p d}$ - the amount of payment delay, thousand $\mathrm{UAH} ; A_{p d}^{\max }, A_{p d}^{a v}, A_{p d}^{\min },-$ maximum, average, minimum amount of loan provision in the previous period, thousand UAH; $I_{p}$ - price index of producers of industrial products (mining industry and development of quarries), $\% ; Z$-discount amount, $\% ; C-$ the interest rate of the bank loan necessary to cover the shortage of working capital, $\% ; m-$ the term of the discount, days.

As a result of the implementation of the mechanism for the formation of the differentiated credit policy at PJSC "Kharkiv Quarry Management" (based on the following data: an increase in the amount of receivables under the moderate type of credit policy is the negative value of $-824.196 \mathrm{UAH}$, which indicates its reduction and release working capital, profit growth in the course of changing the credit policy on the moderate type is 193.200 UAH), it can be noted that the moderate type of credit policy is the most optimal. According to the marketing strategy targeted at market interventions and new clients acquisition, support of the achieved results at the proper level, ensuring sustainable development of the company's activity, and the financial strategy of PJSC "Kharkiv Quarry Management", which is focused on average credit risk, due to crisis phenomena, which are inherent in the modern economy, the instability of market relations between economic entities, the deterioration of their financial status and payment discipline, the chosen credit policy allowed maximizing financial stability, preserving and maximizing competitive position. It should be noted that due to the changing and unstable environmental conditions, the type of credit policy can be revised, if necessary, based on its differentiated nature.

Conclusions. Thus, the experimental introduction of the author's mechanism for the formation of a differentiated credit policy on the basis of controllability of accounts receivable of mining enterprises demonstrated its effectiveness and practical significance, which, in contrast to existing ones:

1) is a synthesis of structured parameters of effective planning, regulation, control, and rational organization of relations with customers in relation to the reverse flow of funds and appropriate methodological tools, differentiated according to the typology of credit policy (conservative, moderate, aggressive) on the basis of controllability of receivables;

2) is flexible at each stage of the formation of the credit policy in accordance with the changing and unstable environmental conditions (fluctuations in market conditions, the impact of competition, and others);
3) has the clear formalization of the results of the calculation of separate structural parameters of credit policy;

4) has the detailed structuring of the parameters of the credit policy (the term of the granting of a deferral of payment, the amount of deferral of payment, the value of the delay of payment), both at the stage of the system of conditions formation of deferral of payment and at the stage of differentiation of the terms of postponement of payment, depending on the class of creditworthiness of buyers (A, B, C, D, E);

5) makes it possible to formulate the unambiguous conclusion on the effectiveness of the credit policy as the whole and for each of its types to determine its optimal type;

6) corresponds to the modern features at mining enterprises.

In order to deepen the conclusions obtained, it is necessary to analyze the effectiveness of the mechanism of collecting receivables, which will be the subject of further research.

\section{References.}

1. Atamanchuk, Y. M., 2015. Features of formation of company credit policy in relation to customers. Investments: practice and experience, 6, pp. 54-59.

2. Kaminskyi, S. I., 2013. Simulation of optimal credit policy of the trade enterprise. Agrosvit, 16, pp. 72-76.

3. Klymenko, O. V., 2013. Improving methodological base for receivables in the monetary policy of enterprise. State and regions, 4(73), pp. 87-91.

4. Nosenko, I. Y., 2016. Problems of accounting and managing accounts receivable. Young Scientist, 12.1(40), pp. 895-900.

5. Masalitina, V.V., 2013. Credit policy of a freight motor transport enterprise and its realization. Visnyk Natsional'noho transportnoho universytetu, 28, pp. 337-342.

6. Chupryna, L. V. and Sheiter, M.A., 2017. Some aspects of managing accounts receivable. Young Scientist, 3(43), pp. 885-889.

7. Anderson, R., 2017. The credit scoring toolkit: theory and practice for retail credit risk management and decision automation: Oxford University Press.

8. Gordon Mills, K. and McCarthy, B., 2014. The State of Small Business Lending: Credit Access during the Recovery and How Technology May Change the Game. - Harvard Business School: Working Paper 15004 [pdf]. Available at: <https://www.hbs.edu/faculty/ Publication\%20Files/15-004_09b1bf8b-eb2a-4e639c4e-0374f770856f.pdf> [Accessed 23 May 2017].

9. State Statistics Service of Ukraine [online]. Available at: <http:// http://www.ukrstat.gov.ua> [Accessed 9 September 2017].

\section{Імплементація диференційованої кредитної політики на підприємстві гірничодобувної промисловості}

\section{Є. В. Кильницька}

Харківський національний університет будівництва та архітектури, м. Харків, Україна, e-mail: dubrochka@ukr.net 
Мета. Експериментальне впровадження розробленого автором механізму формування диференційованої кредитної політики підприємств гірничодобувної промисловості на засадах керованості дебіторської заборгованості.

Методика. Вирішення поставлених у роботі завдань здійснено з використанням сучасних загальнонаукових і спеціальних методів: математичного моделювання - для моделювання наслідків реалізації кредитної політики; абстрактно-логічного для здійснення теоретичних узагальнень, формування висновків і рекомендацій. Крім того, використані результати власних попередніх досліджень iз проблематики управління дебіторською заборгованістю.

Результати. Розроблено механізм формування диференційованої кредитної політики на засадах керованості дебіторської заборгованості, що репрезентує структуровані параметри: 1) встановлення розміру оборотного капіталу, інвестованого в дебіторську заборгованість і розрахунок обсягу продукції на умовах відстрочки платежу; 2) формування системи умов відстрочки платежу (максимально можливий період відстрочки платежу, максимально можливий розмір відстрочки платежу, знижки за дострокове погашення дебіторської заборгованості); 3) диференціація умов відстрочки платежу в залежності від класу кредитоспроможності клієнтів; 4) оцінка доцільності кредитної політики шляхом моделювання впливу результатів іiі впровадження на формування прибутку підприємства. У результаті імплементації механізму формування диференційованої кредитної політики на ПрАТ „Харківське кар'єроуправління“ (грунтуючись на наступних даних: приріст величини дебіторської заборгованості за поміркованого типу кредитної політики є від'ємне значення - 824,196 тис. грн, що свідчить про ії скорочення й вивільнення оборотного капіталу; приріст прибутку при зміні кредитної політики на поміркований тип складає 193,2 тис. грн), можна констатувати, що найоптимальнішім є поміркований тип кредитної політики, що відповідає фінансовій і маркетинговій стратегії підприємства.

Наукова новизна. Розроблено й впроваджено механізм формування диференційованої кредитної політики, що, на відміну від існуючих, є синтезом структурованих параметрів ефективного планування, регулювання, контролю, раціональної організації взаємовідносин із покупцями щодо зворотного руху грошових коштів і відповідного методичного інструментарію, що диференційований відповідно до типології кредитної політики (консервативний, помірний, агресивний) на засадах керованості дебіторської заборгованості.

Практична значимість. Полягає в можливості використання розробленого механізму формування диференційованої кредитної політики, що сприятиме ефективному плануванню, регулюванню, контролю, раціональній організації взаємовідносин із покупцями щодо зворотного руху грошових коштів на підприємствах гірничодобувної промисловості. Експериментальне впровадження авторського механізму формування диференційованої кредитної політики на засадах керованості дебіторської заборгованості в маркетингово-фінансову діяльність підприємств гірничодобувної промисловості підтвердило його дієвість і практичну значимість.

Ключові слова: кредитна політика, дебіторська заборгованість, керованість, підприємства гірничодобувної промисловості, диференціація

\section{Имплементация дифференцированной кредитной политики на предприятии горнодобывающей промышленности}

\section{Е. В. Кильницкая}

Харьковский национальный университет строительства и архитектуры, г. Харьков, Украина, e-mail: dubrochka@ ukr.net

Цель. Экспериментальное внедрение разработанного автором механизма формирования дифференцированной кредитной политики предприятий горнодобывающей промышленности на основе управляемости дебиторской задолженности.

Методика. Решение поставленных в работе задач осуществлено с использованием современных общенаучных и специальных методов: математического моделирования - для моделирования последствий реализации кредитной политики; абстрактно-логического - для осуществления теоретических обобщений, формирования выводов и рекомендаций. Кроме того, использованы результаты собственных предыдущих исследований по проблематике управления дебиторской задолженностью.

Результаты. Разработанный механизм формирования дифференцированной кредитной политики на основе управляемости дебиторской задолженности представляет структурированные параметры: 1) установление размера оборотного капитала, инвестированного в дебиторскую задолженность и расчет объема продукции на условиях отсрочки платежа; 2) формирование системы условий отсрочки платежа (максимально возможный период отсрочки платежа, максимально возможный размер отсрочки платежа, скидки за досрочное погашение дебиторской задолженности); 3) дифференциация условий отсрочки платежа в зависимости от класса кредитоспособности клиентов; 4) оценка целесообразности кредитной политики путем моделирования влияния результатов ее внедрения на формирование прибыли предприятия. В результате имплементации механизма формирования дифференцированной кредитной политики на ЧАО „Харьковское карьероуправление“ (основываясь на следующих данных: прирост величины дебиторской задолженности при умеренном типе кредитной политики представляет отрицательное значение -824,196 тыс. 
грн, что свидетельствует о ее сокращении и высвобождении оборотного капитала; прирост прибыли при изменении кредитной политики на умеренный тип составляет 193,2 тыс. грн), можно констатировать, что оптимальным является умеренный тип кредитной политики, который отвечает финансовой и маркетинговой стратегии предприятия.

Научная новизна. Разработан и внедрен механизм формирования дифференцированной кредитной политики, который, в отличие от существующих, является синтезом структурированных параметров эффективного планирования, регулирования, контроля, рациональной организации взаимоотношений с покупателями относительно обратного движения денежных средств и соответствующего методического инструментария, который дифференцирован согласно типологии кредитной политики (консервативный, умеренный, агрессивный) на основе управляемости дебиторской задолженности.

Практическая значимость. Состоит в возможности использования разработанного механизма формирования дифференцированной кредитной политики, что будет способствовать эффективному планированию, регулированию, контролю, рациональной организации взаимоотношений с покупателями относительно обратного движения денежных средств, на предприятиях горнодобывающей промышленности. Экспериментальное внедрение авторского механизма формирования дифференцированной кредитной политики на основе управляемости дебиторской задолженности в маркетингово-финансовой деятельности предприятий горнодобывающей промышленности подтвердило его действенность и практическую значимость.

Ключевые слова: кредитная политика, дебиторская задолженность, управляемость, предприятие горнодобывающей промышленности, дифференциация

Рекомендовано до публікації докт. екон. наук Л.Л.Калініченко. Дата надходжсення рукопису 27.01.17. 